\title{
The In Vivo Effects of Adenine-Induced Chronic Kidney Disease on Some Renal and Hepatic Function and CYP450 Metabolizing Enzymes
}

\author{
M. AL ZA'ABI ${ }^{1}$, A. SHALABY ${ }^{2}$, P. MANOJ ${ }^{1}$, B. H. ALI ${ }^{1}$ \\ ${ }^{1}$ Department of Pharmacology and Clinical Pharmacy, College of Medicine and Health Sciences, \\ Sultan Qaboos University, Oman, ${ }^{2}$ Department of Pathology, College of Medicine and Health \\ Sciences, Sultan Qaboos University, Oman
}

Received May 13, 2016

Accepted July 15, 2016

On-line December 16, 2016

\begin{abstract}
Summary
Adenine-induced model of chronic kidney disease (CKD) is a widely used model especially in studies testing novel nephroprotective agents. We investigated the effects of adenineinduced CKD in rats on the activities of some xenobiotic metabolizing enzymes in liver and kidneys, and on some in vivo indicators of drug metabolism (viz pentobarbitone sleeping time, and plasma concentration of theophylline $90 \mathrm{~min}$ post administration). CKD was induced by orally feeding adenine $(0.25 \% \mathrm{w} / \mathrm{w})$ for 35 days. Adenine induced all the characteristics of CKD, which was confirmed by biochemical and histological findings. Glutathione concentration and activities of some enzymes involved in its metabolism were reduced in kidneys and livers of rats with CKD. Renal CYP450 1A1 activity was significantly inhibited by adenine, but other measured isoenzymes (1A2, 3A4 and 2E1) were not significantly affected. Adenine significantly prolonged pentobarbitone-sleeping time and increased plasma theophylline concentration $90 \mathrm{~min}$ post administration. Adenine also induced a moderate degree of hepatic damages as indicated histologically and by significant elevations in some plasma enzymes. The results suggest that adenine-induced CKD is associated with significant in vivo inhibitory activities on some drug-metabolizing enzymes, with most of the effect on the kidneys rather than the liver.
\end{abstract}

\section{Key words}

Adenine • Cytochrome P450 • Chronic kidney disease • Drug metabolism

\section{Corresponding author}

M. Al Za'abi, Department of Pharmacology and Clinical Pharmacy, College of Medicine and Health Sciences, Sultan Qaboos
University, P. O. Box 115, Postal code 123-Al Khoud, Oman. E-mail: zaabi@squ.edu.om

\section{Introduction}

Metabolic clearance of many xenobiotics (especially via cytochrome P450) has been reported to be decreased in humans with chronic renal failure (CRF) and chronic kidney disease (CKD) (Michaud et al. 2008, Verbeeck and Musuamba 2009, Philips et al. 2014, Velenosi and Urquhart 2014) and experimental animals with CRF induced by subtotal nephrectomy (Naud et al. 2011, Naud et al. 2012, Dani et al. 2010, Guévin et al. 2002, Velenosi et al. 2012, Feere et al. 2015). Pharmacokinetic studies reported in patients or experimental animals with either acute renal failure (ARF) or CRF suggested that the nonrenal clearance of several drugs is decreased (McIntyre et al. 2002, Srinivas 2010, Sun et al. 2006). Although the mechanism by which this occurs is not well known, several studies have shown that CRF affects the metabolism of drugs by inhibiting key enzymatic systems in the liver, intestine and kidneys (Guévin et al. 2002, Velenosi et al. 2012). It has been suggested that CRF is associated with downregulation of selected hepatic isoforms of cytochrome P450 (CYP450). The enzyme activities of CYP1A2, 2C6, 2C11, 2D1/2D2, 3A2 and 4A1/4A3 were significantly reduced, while CYP2E1 level was not significantly affected (Michaud et al. 2005, Yeung et al. 2014).

Renal dysfunction may affect the metabolism and/or pharmacokinetics of several compounds, and thus 
could have potentially therapeutic and safety consequences (Velenosi and Urquhart 2014, Saito et al. 2014, Krens et al. 2014, Nolin et al. 2009).

The adenine-induced model of CKD was first reported in rats some thirty years ago (Yokozawa et al. 1986), but has recently gained renewed interest, especially in studies testing novel nephroprotective agents such as the prebiotic gum acacia (Ali et al. 2010, Ali et al. 2013a, Ali et al. 2013b, Ali et al. 2014). Therefore, the present work aim is to investigate the effect of adenine-induced CKD on activities of some isoforms of CYP450 in the liver and kidneys rats.

\section{Material and Methods}

\section{Animals}

Male Wistar rats (9-10 weeks old, weighing $249 \pm 10 \mathrm{~g}$ ) were housed at Sultan Qaboos University Small Animals Facility in a room kept at a controlled temperature of $22 \pm 2{ }^{\circ} \mathrm{C}$, relative humidity of about $60 \%$, with a $12 \mathrm{~h} \mathrm{light/dark} \mathrm{cycle} \mathrm{(lights} \mathrm{on} \mathrm{6:00),} \mathrm{and} \mathrm{free}$ access to standard pellet chow diet containing $0.85 \%$ phosphorus, $1.12 \%$ calcium, $0.35 \%$ magnesium, $25.3 \%$ crude protein and $2.5 \mathrm{IU} / \mathrm{g}$ vitamin D3 (Oman Flour Mills, Muscat, Oman) and water. All procedures involving animals and their care were conducted according to international laws and policies (EEC Council directives 86/609, OJ L 358, November 24, 1986; NIH Guide for the Care and Use of Laboratory Animals, NIH Publications No. 85-23, 1985). Ethical clearance was obtained from the Animal Research Ethics Committee of Sultan Qaboos University.

\section{Experimental design}

Three replicated experiments (with 24 rats in each) were conducted. After an acclimatization period of one week, the rats $(n=24$ in each experiment) were randomly divided into two equal groups and treated for five consecutive weeks. The first group continued to receive the same diet without treatment until the end of the study (control group). The second group was switched to a powder diet containing adenine $(0.25 \% \mathrm{w} / \mathrm{w}$ in feed). During the treatment period, the rats were weighted weekly. For the collection of urine, they were placed individually in metabolic cages for $24 \mathrm{~h}$, after the 35 days of treatment.

In the first experiment, and on the morning after the metabolic sampling, the rats were anesthetized with an intraperitoneal injection (i.p.) of ketamine $(75 \mathrm{mg} / \mathrm{kg})$ and xylazine $(5 \mathrm{mg} / \mathrm{kg}$ ), and blood (about $3.5 \mathrm{ml}$ ) was collected from the anterior vena cava and placed into heparinized tubes. The blood and urine were centrifuged at $900 \mathrm{~g}$ at $4{ }^{\circ} \mathrm{C}$ for $15 \mathrm{~min}$. The plasma obtained, together with the urine specimens, was stored at $-80{ }^{\circ} \mathrm{C}$ to await analysis within 4 weeks after the end of the treatment. The left kidney and the same lobe of the liver were excised and immediately snap frozen in liquid nitrogen, and wrapped in aluminum foil and placed in a deep freezer at $-80{ }^{\circ} \mathrm{C}$ pending measurement of some drug metabolizing enzymes. Small pieces of liver and kidney were placed in formal-saline and processed for histopathology as described before (Ali et al. 2013b).

In the second experiment, $24 \mathrm{~h}$ after the last day of treatment, theophylline $(10 \mathrm{mg} / \mathrm{kg})$ was injected i.p. into each of the 24 rats, and $90 \mathrm{~min}$ thereafter, heparinized blood samples were collected from each rat and processed as above to collect plasma. The plasma collected was immediately frozen $\left(-80^{\circ} \mathrm{C}\right)$ pending measurement of theophylline concentration using an automated analyzer Roche/Hitachi Cobas ${ }^{\circledR}$ systems (USA).

In the third experiment, $24 \mathrm{~h}$ after the last day of treatment, rats were injected i.p. pentobarbitone $\mathrm{Na}$, and the onset of sleep and the sleeping time of animals were recorded as described before (Sharif and Ali 1994).

\section{Biochemical measurements}

Renal function tests in plasma (creatinine, urea, creatinine clearance) were measured as described before (Ali et al. 2013b) and the urinary toxin indoxyl sulfate (IS) was measured in plasma by an HPLC method (Al Za'abi et al. 2013). Pieces of liver and kidney from control and treated rats were rinsed with ice-cold PBS ( $\mathrm{pH}$ 7.4) before homogenization in $10 \mathrm{mM}$ phosphate buffer, pH 7.4, containing $0.15 \mathrm{M} \mathrm{KCl}, 0.1 \mathrm{mM}$ EDTA, $1 \mathrm{mM}$ DTT and $0.1 \mathrm{mM}$ phenylmethylsulfonylfluoride at $4{ }^{\circ} \mathrm{C}$. Postmitochondrial (PMS) fractions were prepared by centrifugation as described before (Bhagwat et al. 1999, Raza et al. 2004). Reactive oxygen species in the collected hepatic and renal tissues were measured using either DCFDA as a fluorescent probe or lucigenin based chemiluminescence methods, as described before (Raza et al. 2004, Raza and John 2004). Glutathione (GSH) concentration and enzymes of GSH metabolism in the PMS fractions were measured by standard procedures, as described previously (Habig et al. 1974). CYP 2E1, CYP3A4, CYP1A1 and CYP1A2 activities in the tissues from control and treated rat tissues were measured using 
standard substrates as fully described before (Matsubara et al. 1976).

The plasma L- $\gamma$-glutamyltransferase (GGT) and lactate dehydrogenase (LDH) were measured using kits from Human GmbH (Mannheim, Germany) and Sigma Chemical (St. Louis, MO, USA), respectively. The plasma concentrations of aspartate transaminase (AST), alanine transaminase (ALT), and creatine kinase (CK) were measured using standard laboratory methods by an LX20 multiple automated analyzer (Beckman Coulter, CA, USA).

\section{Drugs and chemicals}

Adenine and substrates for enzymatic activities were obtained from Sigma (St. Louis, MO, USA). All other chemicals used were of analytical reagent grade.

\section{Statistical analysis}

Data are expressed as means \pm SEM. Comparisons between groups were performed by one-way analysis of variance (ANOVA), followed by Newman-Keuls multiple range tests. $P$ values $<0.05$ were considered significant.

\section{Results}

The results of the first experiment (Table 1) showed that, compared with their initial body weight, the control rats have increased their weight by $29 \%$ while the rats fed adenine alone lost about $5 \%$ of their body weight. The urine volume voided by the adenine-treated rats was about five times that of the controls. The renal function biomarkers (creatinine, urea, creatinine clearance, IS and cystatin C) all confirmed that adenine had damaged the renal tissues. The renal histology results (not shown) concurred with earlier data (Ali et al. 2010, 2014, Al Za'abi et al. 2015).

Adenine treatment caused significant and marked increases (about 2-4-fold) in the plasma activities of ALT, AST, CK, GGT and LDH (Table 2).

Figures 1 and 2 depict the renal and hepatic concentration of GSH and activities of some enzymes involved in GSH-dependent metabolism. Renal and hepatic GSH concentrations were significantly reduced by adenine treatment $(P<0.01$ for renal data and $P<0.0001$ for hepatic data). The activity of renal GSSH reductase was significantly inhibited by adenine and the activities of the enzymes GST and GSSG were both insignificantly inhibited in renal (but not hepatic) tissues in adenine-treated rats.

Table 1. Effect of adenine-induced chronic renal failure on body weight change, urine volume and renal function tests in plasma of rats.

\begin{tabular}{lcc}
$\begin{array}{l}\text { Parameters/ } \\
\text { Groups }\end{array}$ & Control & Adenine \\
\hline $\begin{array}{l}\text { Initial body weight } \\
\text { (g) }\end{array}$ & $245.5 \pm 3.4$ & $242.6 \pm 6.3$ \\
$\begin{array}{l}\text { Final body weight } \\
\text { (g) }\end{array}$ & $304.5 \pm 5.6$ & $233.0 \pm 6.9$ \\
$\begin{array}{l}\text { \% difference } \\
\text { between initial and } \\
\text { final body weight }\end{array}$ & $28.5 \pm 2.3$ & $-5.1 \pm 1.9^{* * *}$ \\
$\begin{array}{l}\text { Urine voided } \\
\text { (ml/24 } \text { h) }\end{array}$ & \\
$\begin{array}{l}\text { Plasma creatinine } \\
\text { (mmol/l) }\end{array}$ & $32.2 \pm 1.7$ & $107.9 \pm 17.3^{* * *}$ \\
$\begin{array}{l}\text { Plasma urea } \\
\text { (mmol/l) }\end{array}$ & \\
$\begin{array}{l}\text { Creatinine } \\
\text { clearance (ml/min) } \\
\text { Plasma indoxyl } \\
\text { sulfate ( } \mu \text { mol) }\end{array}$ & $0.03 \pm 0.003$ & $0.002 \pm 0.0005^{* * *}$ \\
$\begin{array}{l}\text { Plasma cystatin C } \\
\text { (mg/ml) }\end{array}$ & $2.15 \pm 0.8$ & $72.2 \pm 3.3^{* * *}$ \\
\hline
\end{tabular}

Values are means $\pm \operatorname{SEM}(n=6)$. Rats were given adenine in the feed at a concentration of $0.25 \%$ for 35 days. $* P<0.05$, $* * P<0.001, * * * P<0.0001$ (compared with controls).

Table 2. Effect of adenine-induced chronic kidney disease on the plasma activities of some hepatic enzymes.

\begin{tabular}{lcc}
\hline Enzymes & Control & Adenine \\
\hline$A L T(I U / l)$ & $28.0 \pm 3.9$ & $113.2 \pm 24.9^{* * *}$ \\
$A S T(I U / l)$ & $40.2 \pm 3.9$ & $126.3 \pm 21.6^{* * *}$ \\
$C K(U / l)$ & $265.0 \pm 24.3$ & $453.3 \pm 13.5^{* *}$ \\
$G G T(U / l)$ & $1.5 \pm 0.3$ & $5.3 \pm 0.6^{* * *}$ \\
$L D H(I U / l)$ & $189.0 \pm 14.2$ & $358.7 \pm 16.9^{* * *}$ \\
\hline
\end{tabular}

Data are means \pm SEM $(n=6)$. Rats were given either adenine $(0.25 \% \mathrm{w} / \mathrm{v}$ in feed, 5 weeks). ALT - alanine transaminase, AST - aspartate transaminase, CK - creatine kinase, GGT L-y-glutamyltransferase, LDH - lactate dehydrogenase. $* P<0.05$, $* * P<0.001$, $* * * P<0.0001$ (compared with controls). 

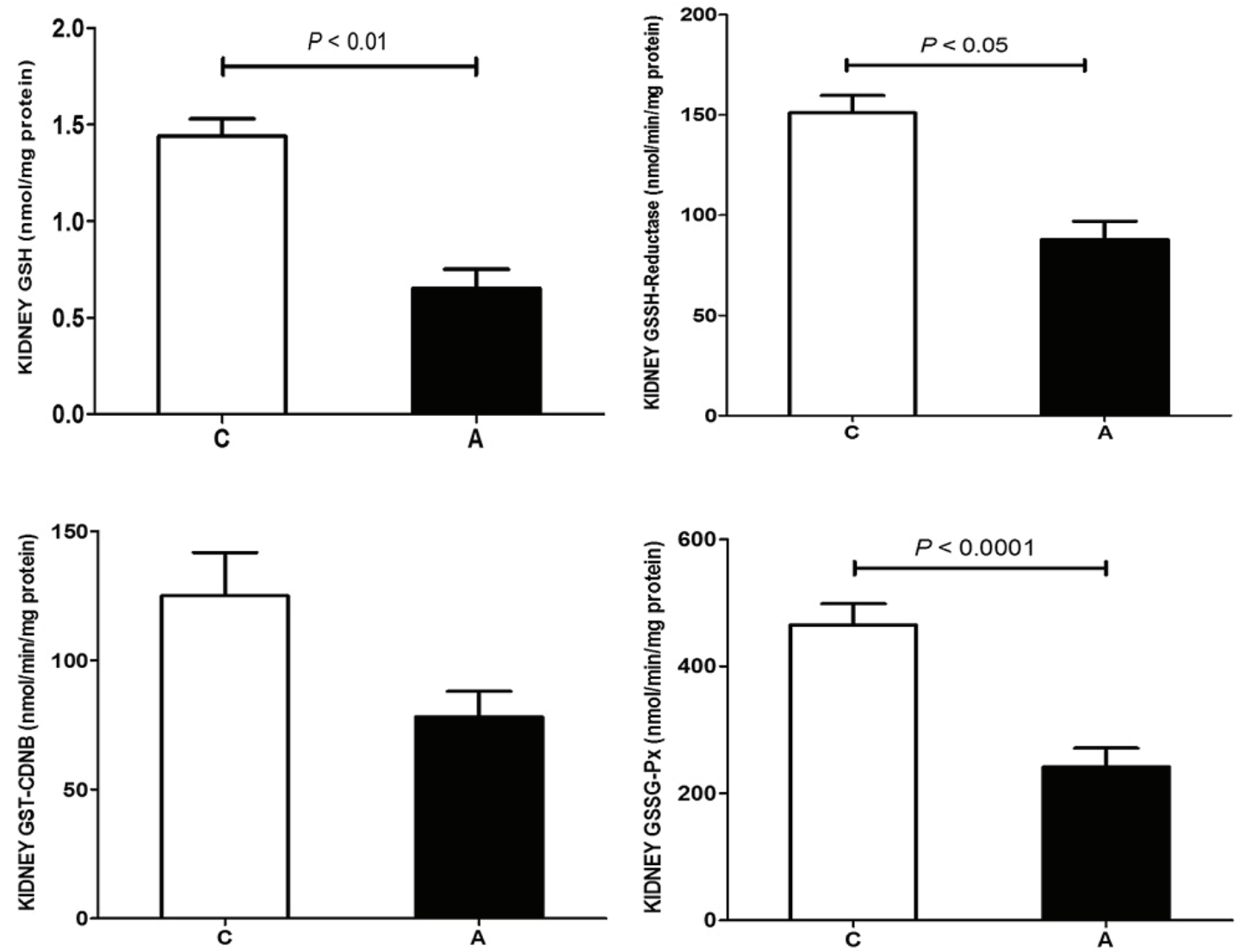

Fig. 1. The effect of adenine treatment on the renal activities of reduced glutathione (GSH) and enzymes involved in its metabolism in control rats ( $C$, white column), and rats treated with adenine $(0.25 \% \mathrm{w} / \mathrm{w}, 5$ weeks) (A, black column).
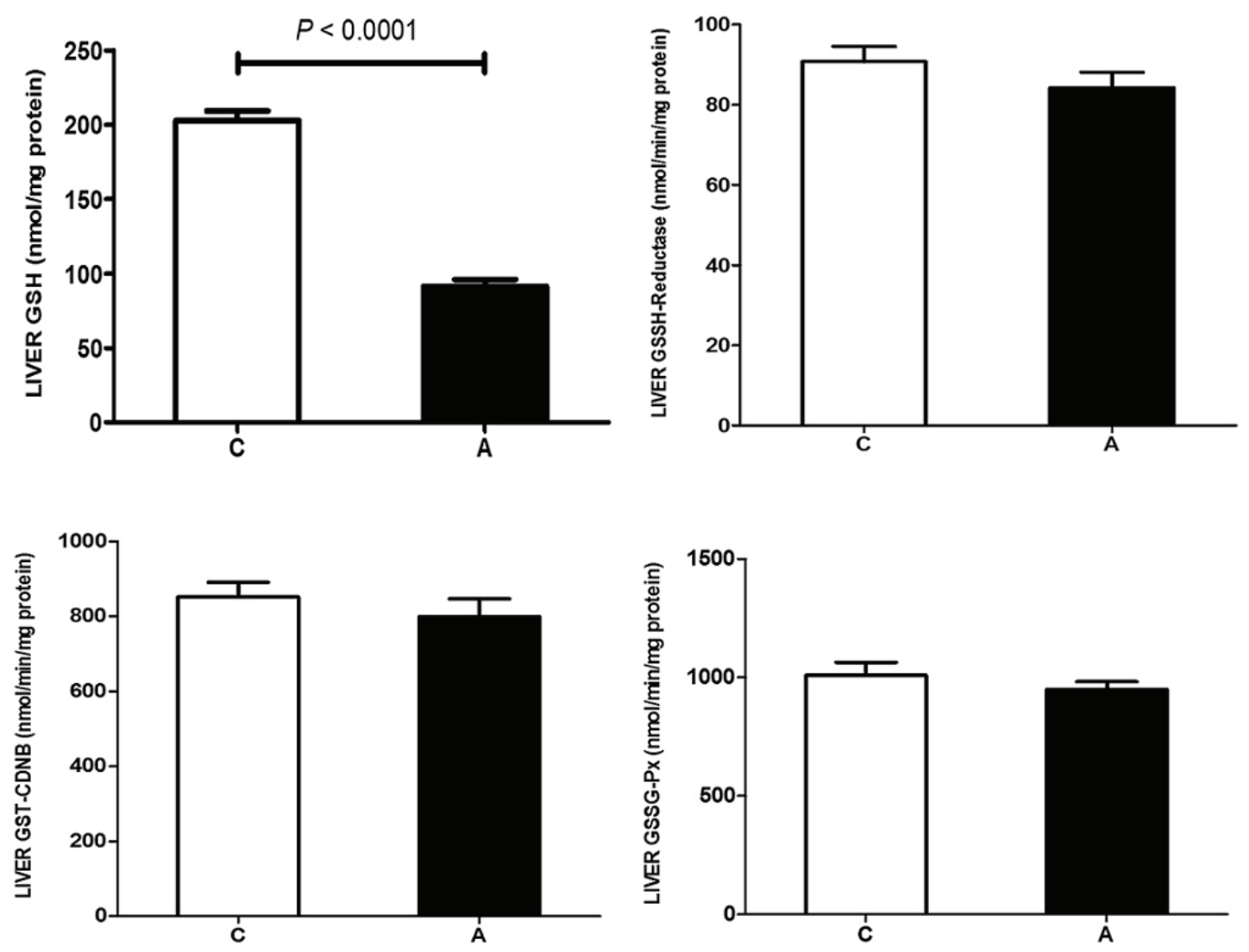

Fig. 2. The effect of adenine treatment on the hepatic activities of reduced glutathione (GSH) and enzymes involved in its metabolism in control rats ( $C$, white column), and rats treated with adenine $(0.25 \% \mathrm{w} / \mathrm{w}, 5$ weeks) (A, black column). 

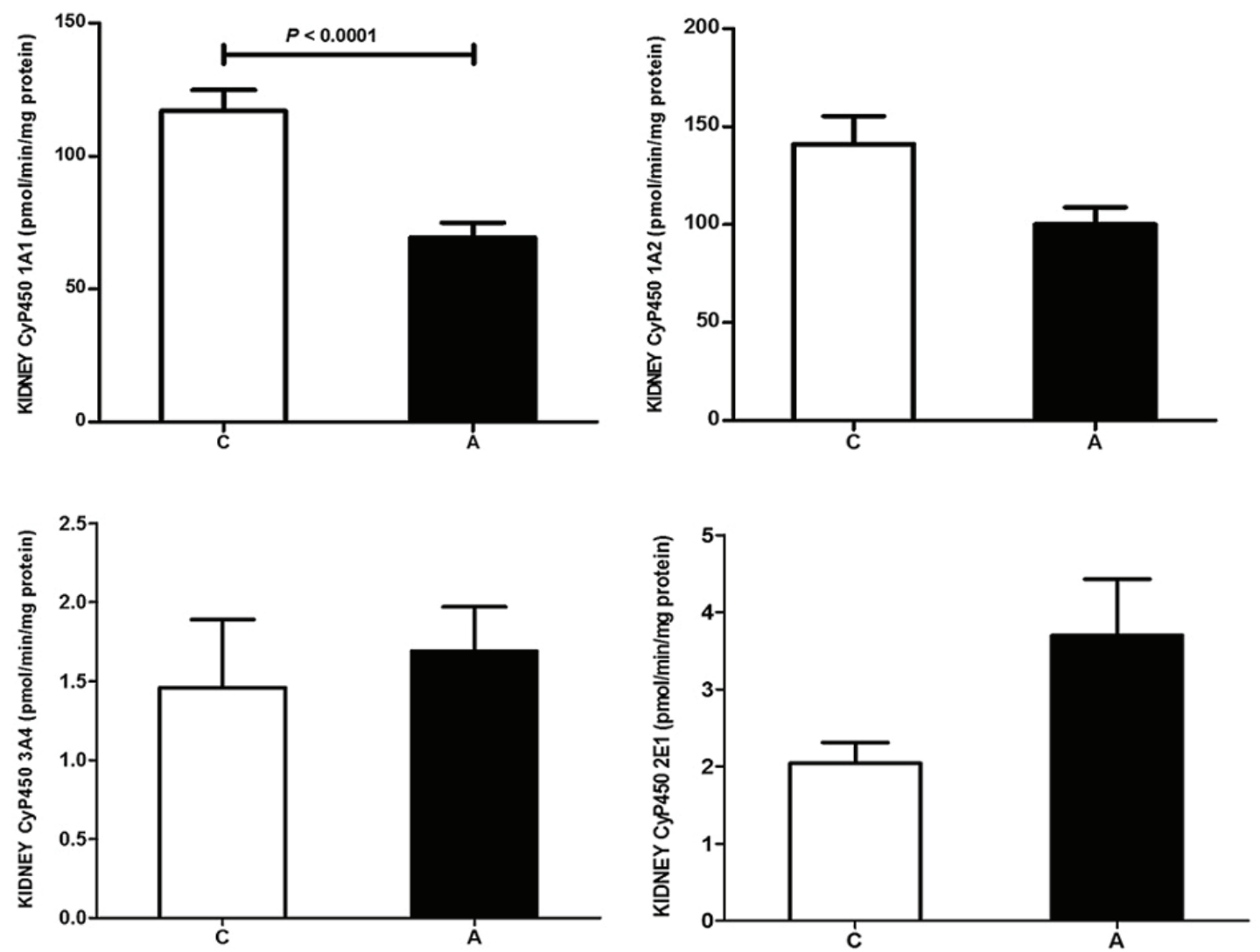

Fig. 3. The effect of adenine treatment on the renal activities of isoenzymes of cytochrome $P-450$ in control rats (C, white column), and rats treated with adenine ( $0.25 \% \mathrm{w} / \mathrm{w}, 5$ weeks) (A, black column).
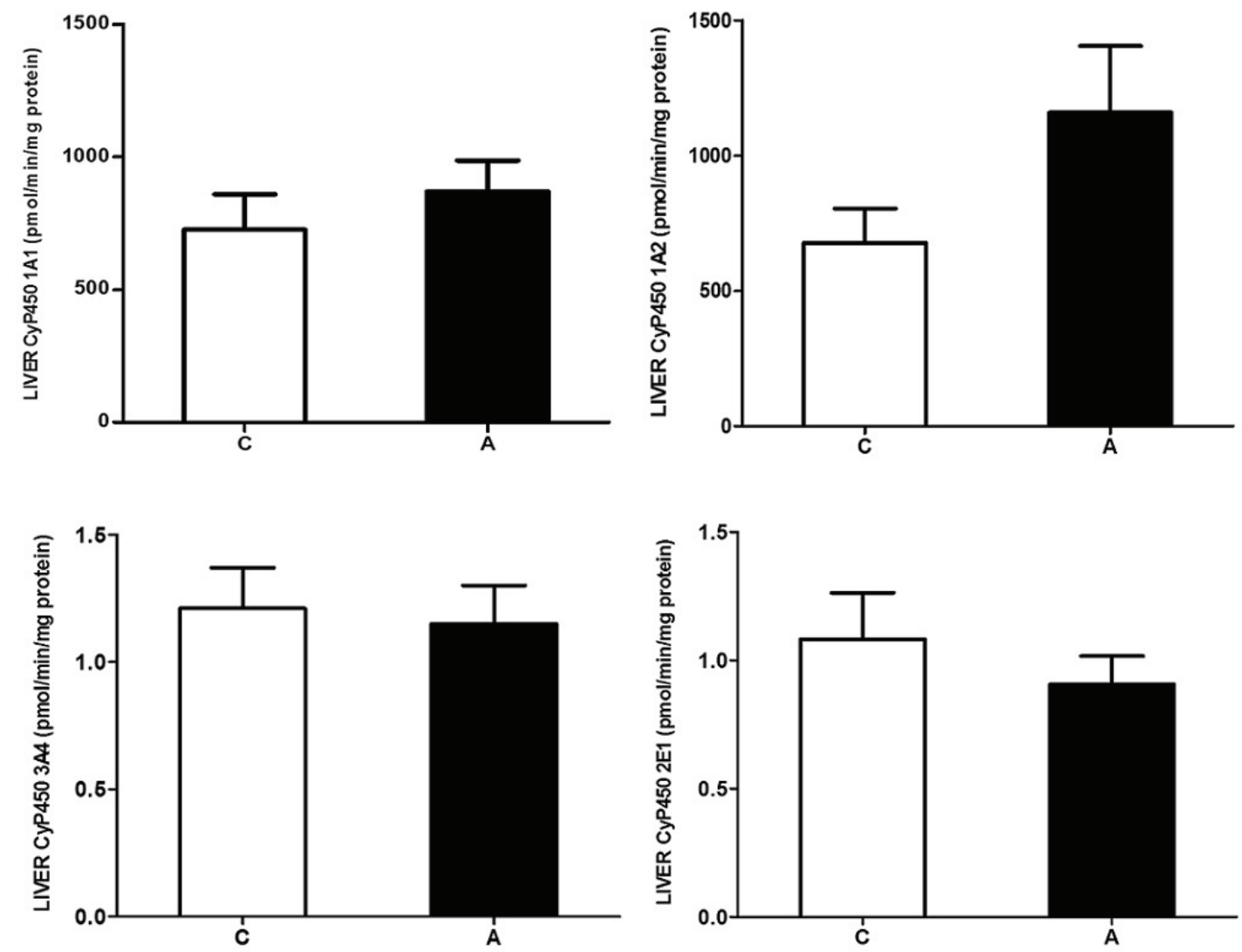

Fig. 4. The effect of adenine treatment on the hepatic activities of isoenzymes of cytochrome $P-450$ in control rats (C, white column), and rats treated with adenine ( $0.25 \% \mathrm{w} / \mathrm{w}, 5$ weeks) (A, black column). 


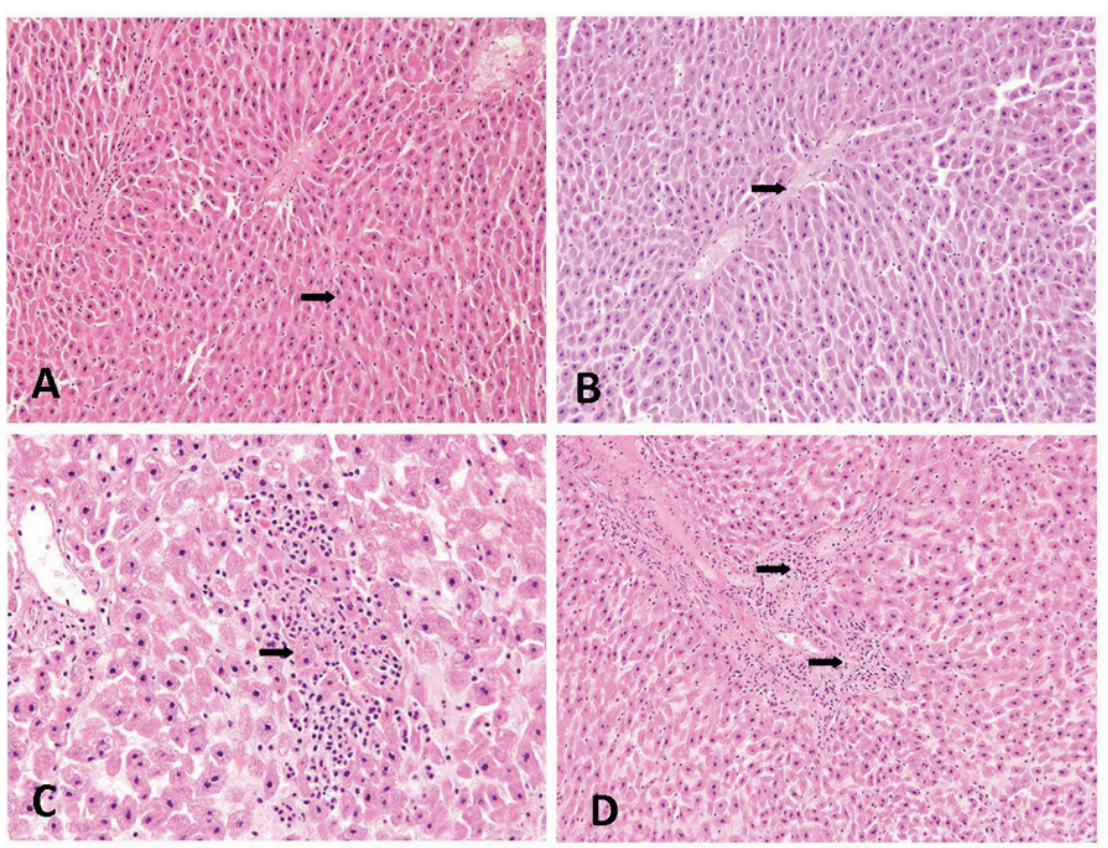

Fig. 5. A representative photomicrograph showing liver tissue from control with intact parenchyma (A) and portal area without inflammatory infiltrate (B). Liver tissue treated with adenine shows inflammatory infiltration in the parenchyma (C) and portal areas (D).

Figures 3 and 4 show the renal and hepatic activities of some isoenzymes of CYP450. Renal CYP450 1A1 was significantly inhibited $(P<0.001)$ in renal (but not hepatic) tissues of rats with adenine $C K D$, while the rest of the isoforms of the enzymes in the renal and hepatic tissues were insignificantly affected by adenine.

Liver tissue from the control shows intact parenchymal tissue with no lobular inflammation (Fig. 5A), and portal areas show either no or minimal inflammatory infiltrates (Fig. 5B). The liver tissue treated with adenine shows infiltration of the liver tissue with inflammatory cells (lobular inflammation, Fig. 5C). The portal areas show mild to moderate round cell inflammatory infiltrate (Fig. 5D).

Table 3. Pentobarbitone sleeping time and theophylline plasma concentration in rats treated with adenine.

\begin{tabular}{llcc}
\hline Group & Treatment & $\begin{array}{c}\text { Pentobarbitone } \\
\text { sleeping time } \\
(\mathbf{m i n})\end{array}$ & $\begin{array}{c}\text { Theophylline } \\
\text { concentration } \\
(\boldsymbol{\mu m o l} / \mathbf{l})\end{array}$ \\
\hline 1 & Control & $30.5 \pm 0.5$ & $62.5+2.8$ \\
2 & Adenine & $70.5 \pm 4.1^{*}$ & $74.4 \pm 1.1^{*}$ \\
\hline
\end{tabular}

Data are means $\pm \operatorname{SEM}(n=6)$. Rats were given adenine $(0.25 \%$ $\mathrm{w} / \mathrm{v}$ in feed, 5 weeks). In one experiment, rats were anesthetized by pentobarbitone $(40 \mathrm{mg} / \mathrm{kg}$, intraperitoneally) and the sleeping time was measured. In another experiment, the animals were injected intraperitoneally with theophylline $(10 \mathrm{mg} / \mathrm{kg}) 24 \mathrm{~h}$ before sacrifice, and blood was collected 90 min later. $* P<0.05$ (compared with controls).
Table 3 shows the effect of adenine-induced CKD on the pentobarbitone-sleeping time and theophylline concentration $90 \mathrm{~min}$ post administration. Adenine treatment produced significant increases in both when compared with the values obtained from the control rats $(P<0.05)$.

\section{Discussion}

It is established that hepatic CYP450 enzymes contribute directly to the metabolism of a wide array of xenobiotics via oxidation, reduction and hydrolysis. These enzymes are also present in the renal tissues in significant amounts (Feere et al. 2015). Therefore, it was of interest to find out whether adenine-induced CKD would affect the CYP450 enzymes in both the liver and the kidneys. It has long been known that extensive renal damage resulting in end-stage renal failure would also result in hepatic dysfunction, an action probably mediated by the generation of uremic toxins (Pichette and Leblond 2004). Also, some hepatic CYP450 isoenzymes are downregulated in rats with moderate CKD (Velenosi et al. 2012).

In a recent review article on drug disposition in several models of acute renal failure (ARF), it was suggested that this condition can lead to decreased renal elimination of the drug and associated metabolites (Srinivas 2010). However, its influence on the overall body clearance depends on the propensity of the contribution of renal versus nonrenal mechanisms of elimination. More recently, it was reported that the 
influence of CKD on nonrenal drug clearance is increasingly apparent, and is now deemed an important factor by the Food and Drug Administration in the recommendation of drug dosage in CKD patients (Velenosi and Urquhart 2014). CRF and even moderate $\mathrm{CKD}$ in rats have been suggested to downregulate some hepatic CYP450 isoenzymes, possibly via mediation of some uremic toxins (Saito et al. 2014).

In the present work, we have shown that, on the whole, the GSH and the enzymes involved in its metabolism, as well as CYP1A1 were much more affected by the inhibitory action of adenine in the kidneys than in the liver. This may suggest that the kidneys are the predilection site of adenine, in which this agent is metabolized into a toxic compound that accumulates in the renal tissues. Velonosi et al. (2012) have reported that the activity and expression of hepatic CYP3A and CYP2C are both decreased in both moderate and severe surgically-induced CKD. Their data suggest that hepatic drug metabolism is significantly decreased in the earlier stages of CKD. In our results we did not show any significant change in the activity of CYP3A in the liver or kidneys of rats with a rather moderate CKD. Hepatic CYP3A is suggested to mediate nonrenal clearance of many drugs, and is involved in the oxidative metabolism of $\sim 30 \%$ (Thomson et al. 2015) or up to $50 \%$ of all drugs on the market (Velenosi and Urquhart 2014). The reason for the discrepancy is not certain, especially when we have found that, functionally, adenine-induced CKD actually significantly lessened the metabolism of pentobarbitone. The plasma concentration of theophylline, which is a probe drug metabolized in the liver and kidneys by CYP1A, 90 min post administration was found to be significantly increased. This may suggest a lack of correlation between these functional parameters and the activities of drug metabolizing enzymes.

Interestingly, Feere et al. (2015) have shown that the liver histology was normal in an adenine-induced model of CKD, yet their data on the activity of two plasma enzymes, ALT and AST (measured as hepatic functions tests), indicated that the activities of these enzymes had been significantly inhibited four- and twofold, respectively, while the hepatic total CYP450 content was halved. Contrary to these data we have found, as well as others, that the activities of these plasma enzymes are elevated and not inhibited (Al Za'abi et al. 2015, Kim et al. 2013, Manivannan et al. 2013). This probably indicates some tissue damage in the liver in adeninetreated rats, which is at variance with results obtained by Feere et al. (2015). In addition, our hepatic histology showed inflammatory infiltration of the portal and hepatic area (Fig. 3) suggesting some degree of tissue damage. However, we are not certain whether the degree and the extent of this damage explain the discrepancy in our results to the findings of Feere et al. (2015). Furthermore, it is not possible at this stage to conclude that the observed effects on liver are either due adenine-induced CKD or direct toxic effect of adenine on the hepatic cells. Further histological and other specific hepatic function tests are required to ascertain the status of the liver in adenine-induced CKD. It is also worth mentioning that the liver-specific enzymes are known to be elevated more in acute rather than chronic kidney damage (Srinivas 2010).

\section{Conclusion}

Our data have suggested that adenine-induced CKD inhibited the activities of some drug-metabolizing enzymes, with most of the effect on the kidneys, rather than the liver. However, the condition is associated with significant in vivo effects related to hepatic and renal metabolism.

\section{Conflict of Interest}

There is no conflict of interest.

\section{Acknowledgements}

This work was supported by Sultan Qaboos University, Oman (IG/MED/PHAR/15/02). Thanks are due to Professor Haider Raza, United Arab Emirate University for his help with measuring the enzyme activities, Professor A. Nemmar for his interest and advice, Mr. Romulo Sciprano for measuring theophylline plasma concentration, and Professor Gerry Blunden for checking the language of the manuscript.

\section{References}

ALI BH, AL-HUSSENI I, BEEGAM S, AL-SHUKAILI A, NEMMAR A, SCHIERLING S, QUEISSER N, SCHUPP $\mathrm{N}$ : Effects of gum arabic in rats with adenine-induced chronic renal failure. Exp Biol Med (Maywood) 235 : $373-382,2010$. 
ALI BH, AL-SALAM S, Al ZA’ABI M, WALY MI, RAMKUMAR A, BEEGAM S, AL-LAWATI I, ADHAM SA, NEMMAR A: New model for adenine-induced chronic renal failure in mice, and the effect of gum acacia treatment thereon: comparison with rats. J Pharmacol Toxicol Methods 68: 384-393, $2013 \mathrm{a}$.

ALI BH, BEEGAM S, AL-LAWATI I, WALY MI, AL ZA'ABI M, NEMMAR A: Comparative efficacy of three brands of gum acacia on adenine-induced chronic renal failure in rats. Physiol Res 62: 47-56, $2013 \mathrm{~b}$.

ALI BH, AL-SALAM S, AL ZA'ABI M, AL BALUSHI KA, RAMKUMAR A, WALY MI, YASIN J, ADHAM SA, NEMMAR A: Does swimming exercise affect experimental chronic kidney disease in rats treated with gum acacia? PLoS One 9: e102528, 2014.

AL ZA'ABI M, ALI B, AL TOUBI M: HPLC-fluorescence method for measurement of the uremic toxin indoxyl sulfate in plasma. J Chromatogr Sci 51: 40-43, 2013.

AL ZA'ABI M, AL BUSAIDI M, YASIN J, SCHUPP N, NEMMAR A, ALI BH: Development of a new model for the induction of chronic kidney disease via intraperitoneal adenine administration, and the effect of treatment with gum acacia thereon. Am J Transl Res 7: 28-38, 2015.

BHAGWAT SV, MULLICK J, RAZA H, AVADHANI NG: Constitutive and inducible cytochromes P450 in rat lung mitochondria: xenobiotic induction, relative abundance, and catalytic properties. Toxicol Appl Pharmacol 156: 231-240, 1999.

DANI M, BOISVERT C, MICHAUD J, NAUD J, LEFRANCOIS S, LEBLOND FA, PICHETTE V: Down-regulation of liver drug-metabolizing enzymes in a murine model of chronic renal failure. Drug Metab Dispos 38: 357-360, 2010.

FEERE DA, VELENOSI TJ, URQUHART BL: Effect of erythropoietin on hepatic cytochrome P450 expression and function in an adenine-fed rat model of chronic kidney disease. Br J Pharmacol 172: 201-213, 2015.

GUEVIN C, MICHAUD J, NAUD J, LEBLOND FA, PICHETTE V: Down-regulation of hepatic cytochrome p450 in chronic renal failure: role of uremic mediators. Br J Pharmacol 137: 1039-1046, 2002.

HABIG WH, PABST MJ, JAKOBY WB: Glutathione S-transferase, the first enzymatic step in mercapturic acid formation. J Biol Chem 49: 7130-7139, 1974.

KIM EJ, OH HA, CHOI HJ, PARK JH, KIM DH, KIM NJ: Heat-processed ginseng saponin ameliorates the adenineinduced renal failure in rats. $J$ Ginseng Res 37: 87-93, 2013.

KRENS LL, BAAS JM, VERBOOM MC, PAINTAUD G, DESVIGNES C, GUCHELAAR HJ, GELDERBLOM H: Pharmacokinetics and safety of cetuximab in a patient with renal dysfunction. Cancer Chemother Pharmacol 73: 1303-1306, 2014.

MANIVANNAN J, BARATHKUMAR TR, SIVASUBRAMANIAN J, ARUNAGIRI P, RAJA B, BALAMURUGAN E: Diosgenin attenuates vascular calcification in chronic renal failure rats. Mol Cell Biochem 378: 9-18, 2013.

MATSUBARA T, KOIKE M, TOUCHI A, TOCHINO Y, SUGENO K: Quantitative determination of cytochrome P-450 in rat liver homogenate. Anal Biochem 75: 596-603, 1976.

MCLINTYRE CW, FLUCK RJ, FREEMAN JG, LAMBIE SH: Characterization of treatment dose delivered by albumin dialysis in the treatment of acute renal failure associated with severe hepatic dysfunction. Clin Nephrol 58: 376-383, 2002.

MICHAUD J, DUBE P, NAUD J, LEBLOND FA, DESBIENS K, BONNARDEAUX A, PICHETTE V: Effects of serum from patients with chronic renal failure on rat hepatic cytochrome P450. Br J Pharmacol 144: 1067-1077, 2005.

MICHAUD J, NOLIN TD, NAUD J, DANI M, LARFRANE JP, LEBLOND FA, HIMMELFARB J, PICHETTE V: Effect of hemodialysis on hepatic cytochrome P450 functional expression. J Pharmacol Sci 108: 157-163, 2008.

NAUD J, MICHAUD J, BEAUCHEMIN S, HEBERT MJ, ROGER M, LARFRANE JP, LEBLOND FA, PICHETTE V: Effects of chronic renal failure on kidney drug transporters and cytochrome P450 in rats. Drug Metab Dispos 39: 1363-1369, 2011.

NAUD J, LAURIN LP, MICHAUD J, BEAUCHEMIN S, LEBLOND FA, PICHETTE V: Effects of chronic renal failure on brain drug transporters in rats. Drug Metab Dispos 40: 39-46, 2012.

NOLIN TD, FRYE RF, LE P, SADR H, NAUD J, LEBLOND FA, PICHETTE V, HIMMELFARB J: ESRD impairs nonrenal clearance of fexofenadine but not midazolam. J Am Soc Nephrol 20: 2269-2276, 2009. 
PHILIPS BJ, LANE K, DIXON J, MACPHEE I: The effects of acute renal failure on drug metabolism. Expert Opin Drug Metab Toxicol 10: 11-23, 2014.

PICHETTE V, LEBLOND FA: Drug metabolism in chronic renal failure. Curr Drug Metab 4: 91-103, 2003.

RAZA H, JOHN A: Glutathione metabolism and oxidative stress in neonatal rat tissues from streptozotocin-induced diabetic mothers. Diabetes Metab Res Rev 20: 72-78, 2004.

RAZA H, PRABUE SK, ROBIN MA, AVADHANI NG: Elevated mitochondrial cytochrome P450 2E1 and glutathione S-transferase A4-4 in streptozotocin-induced diabetic rats: tissue-specific variations and roles in oxidative stress. Diabetes 53: 185-194, 2004.

SAITO H, YOSHIMURA M, SAIGO C, KOMORI M, NOMURA Y, YAMAMOTO Y, SAGATA M, WAKIDA A, CHUMAN E, NISHI K, JONO H: Hepatic sulfotransferase as a nephropreventing target by suppression of the uremic toxin indoxyl sulfate accumulation in ischemic acute kidney injury. Toxicol Sci 141: 206-217, 2014.

SHARIF SI, ALI BH: Effect of grapefruit juice on drug metabolism in rats. Food Chem Toxicol 32: 1169-1171, 1994.

SRINIVAS NR: Altered disposition of drugs in acute renal failure rat models: drug development strategies and perspectives. Arzneimittelforschung 60: 731-748, 2010.

SUN H, FRASSETTO L, BENET LZ: Effects of renal failure on drug transport and metabolism. Pharmacol Ther 109: $1-11,2006$.

THOMSON BK, NOLIN TD, VELENOSI TJ, FEERE DA, KNAUER MJ, ASHER LJ, HOUSE AA, URQUHART BL: Effect of CKD and dialysis modality on exposure to drugs cleared by nonrenal mechanisms. Am J Kidney Dis 65: 574-582, 2015.

VELENOSI TJ, URQUHART BL: Pharmacokinetic considerations in chronic kidney disease and patients requiring dialysis. Expert Opin Drug Metab Toxicol 10: 1131-1143, 2014.

VELENOSI TJ, FU AY, LUO S, WANG H, URQUHART BL: Down-regulation of hepatic CYP3A and CYP2C mediated metabolism in rats with moderate chronic kidney disease. Drug Metab Dispos 40: 1508-1514, 2012.

VERBEECK RK, MUSUAMBA FT: Pharmacokinetics and dosage adjustment in patients with renal dysfunction. Eur $J$ Clin Pharmacol 65: 757-773, 2009.

YEUNG CK, SHEN DD, THUMMEL KE, HIMMELFARB J: Effects of chronic kidney disease and uremia on hepatic drug metabolism and transport. Kidney Int 85: 522-528, 2014.

YOKOZAWA T, ZHENG PD, OURA H, KOIZUMI F: Animal model of adenine-induced chronic renal failure in rats. Nephron 44: 230-234, 1986. 